\title{
Validity and Practically of Learning Resources Flipbook Identification of Basidiomycota Mushrooms for Senior High School Students
}

Fajrul Falah ${ }^{1}$, Sifak Indana ${ }^{2}$, Tukiran ${ }^{3}$

1,2,3 Universitas Negeri Surabaya, Surabaya, Indonesia

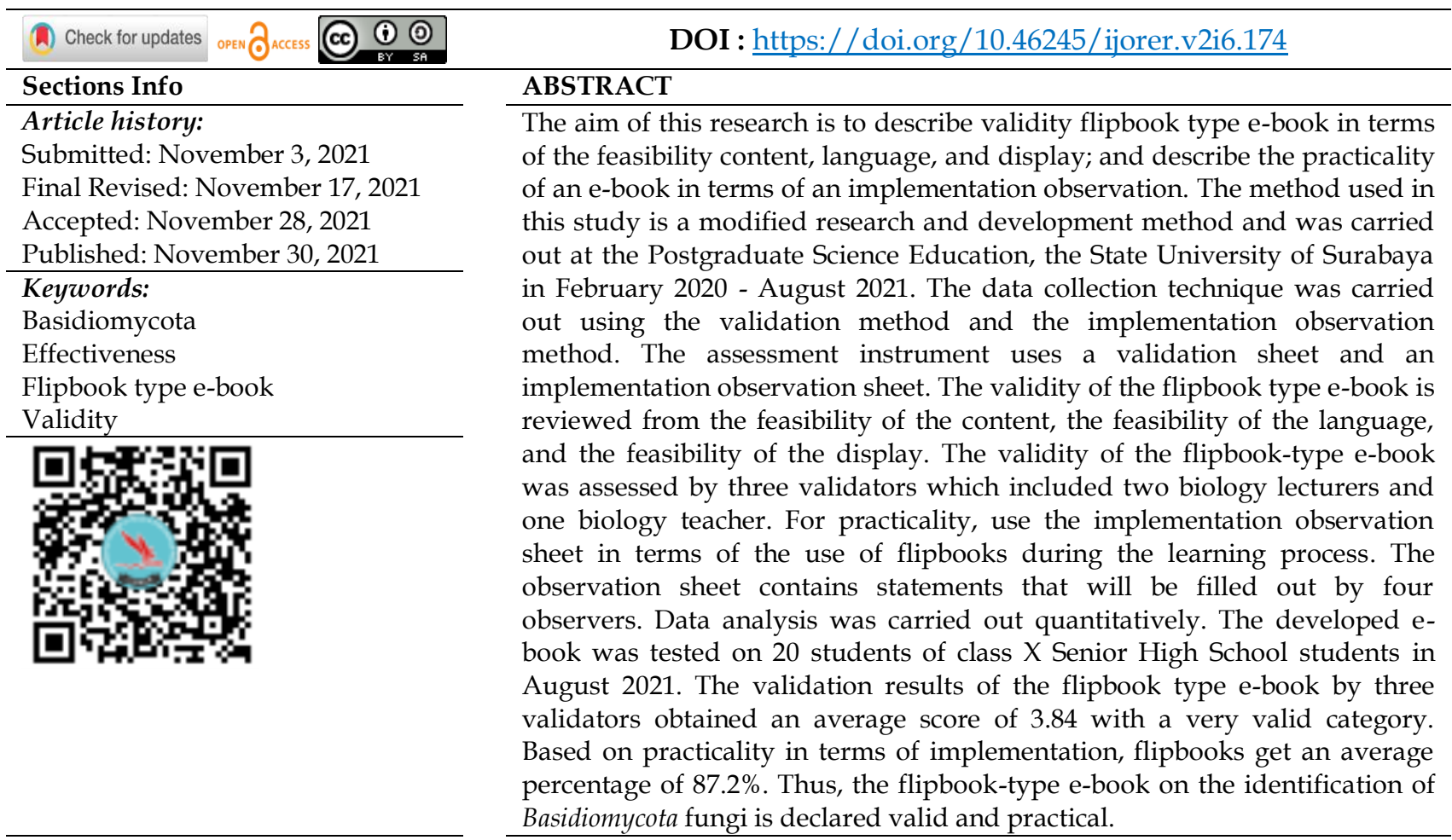

\section{INTRODUCTION}

Curriculum 2013 is a curriculum that requires students to be active during learning, think critically, and find a concept by using their knowledge and skills. Biology learning activities in the 2013 curriculum are limited to mastering the material and include finding concepts based on facts that exist in nature. Biology is a lesson that applies the knowledge that has been obtained about living things and their relationship with the environment. One of the materials in biology learning contained in the 2013 curriculum syllabus is Mushroom material. The material for fungi or fungi in the revised 2013 curriculum is organized in Basic Competencies (i.e. KD) 3.7, namely Grouping fungi based on characteristics, reproduction methods, and linking their roles in life and 4.7 Presenting reports on the results of investigations on the diversity of fungi and their roles in life. One of the factors that influence the achievement in completing the KD is learning resources. It is due to learning resources as a support and means of learning aids for students in learning activities. Awaludin (2017) states that teaching materials are part of learning tools for teachers or lecturers to improve student learning outcomes.

In connection with the use of these learning resources, it is obtained that so far, the Mushroom material still does not have teaching materials specifically made to achieve the predetermined Basic Competencies. Learning resources owned by students are still 
not available for specific types and types of mushrooms, so that students still have difficulty in identifying and classifying types of mushrooms. In addition, the textbooks owned by students have a heavy size so that they are not used optimally. This follows the statement of Fithriyah and As'ari (2013), which states that textbooks are less able to be utilized optimally by students because they are large and heavy to carry.

Due to the lack of examples and pictures of mushrooms, students have difficulty distinguishing and identifying various types of mushrooms in their environment. Based on the results of the pre-research that had been conducted at SMA Negeri 1 Bareng Jombang through a questionnaire to 15 students of class X MIPA 4, as many as $86.66 \%$ of the students stated that they still had difficulty in distinguishing the various types of mushrooms that existed in their environment. The lack of examples and pictures of mushrooms available in textbooks causes students to have trouble determining and identifying types of mushrooms, so students' learning motivation is low. Sanjaya in Lubis (2015) states that underachieving students are not caused by lack of ability but due to lack of motivation to learn so they do not try to optimize all their abilities.

Motivation is a change in energy from within a person's personality which is marked by the emergence of feelings and the power to act (Uno, 2015). With strong motivation, learning efforts will increase and can produce good student learning achievements (Handika, 2012). Keller classifies learning motivation into four components known as the ARCS learning model: attention, relevance, confidence, and satisfaction. Prasetyo et al (2015) states that motivation can be defined as something that can cause students to be encouraged to learn, make students keep learning, and determine what students want to learn to achieve the desired goal, namely learning success.

One solution that can be done to solve these problems is to develop learning media that can increase students' learning motivation. Learning motivation can be interpreted as encouragement, strength, need pressure, enthusiasm, or a person's psychological mechanism that can cause the creation of a will to carry out activities that can be sourced from within or from outside each individual (Sardiman, 2014).

The role of learning media can also be used to increase students' learning motivation (Hess, 2014). Learning media in the form of electronic books or electronic books (ebooks) can be an alternative to increasing students' learning motivation. E-books have an attractive appearance so that they can increase learning motivation and make it easier for students to receive learning materials that have been provided. The research that has been done by Sakat et al. (2012) that the use of technology-based media in learning can increase learning motivation and make learning more attractive, fun, and interesting. There are many benefits obtained from using e-books, one of which is the benefits of multimedia tools (audio, video, and animation) that can attract students' attention (Daniel et al., 2018). E-books are one of the most needed teaching materials at this time. This is because considering the COVID-19 pandemic, where educators or teachers must ensure that teaching and learning activities are carried out, even though students are at home. With these conditions, teachers are required to be able to design learning media in such a way that they can be accessed by students online.

E-books can be a practical learning medium used by students and teachers. According to research conducted, electronic book media has several advantages, including 1) The process of learning activities becomes clearer and more interesting, 2) e-books can be brought and read anywhere and anytime. Without the need for additional devices to access it, and 3) in the form of interactive learning media so that students read a collection of readings and find out in detail the complete picture in the 
Feasibility and Practically of Learning Resources Flipbook Identification of Basidiomycota Mushrooms for Senior High School Students

book. E-books have become a sophisticated technological innovation that is expected to develop over time to replace traditional paper books for the prospective future. Focus this research on analyzing the validity and practicality of learning resources flipbook identification of Basidiomycota mushrooms for senior high school students.

\section{RESEARCH METHODS}

This research is a type of development research, namely developing a flipbook type ebook learning media that refers to the Research and Development (R\&D) development research design. The R\&D research design includes the stages of Research and Development (Figure 1). The flipbook-type e-book trial was carried out in August of the 2020/2021 school year for class X high school students with a sample of 20 students. This study consists of single data, which adjusts to the conditions of students during the COVID-19 pandemic so that it adapts to the application of learning in schools. Data collection was carried out using validation methods and implementation observations. The assessment instrument uses a validation sheet and an implementation observation sheet.

The validity of the flipbook type e-book is reviewed from the feasibility of the content, language, and appearance of the e-book. Validation was carried out by three validators, which included two expert lecturers and one biology teacher. The data from the validation results were then analyzed by calculating the average value of the scores given by the validator. The average score data was obtained then analyzed using a Likert Scale.

Table 1. Likert scale score criteria.

\begin{tabular}{cc}
\hline Criteria & Score \\
\hline Very Good & 4 \\
Good & 3 \\
Quite Good & 2 \\
Not Good & 1 \\
\hline
\end{tabular}

Based on the score scale, then the percentage of validity will be calculated using the formula:

$$
V=\frac{\sum \text { score each criteria }}{\sum \text { score each criteria }} \times 100 \%
$$




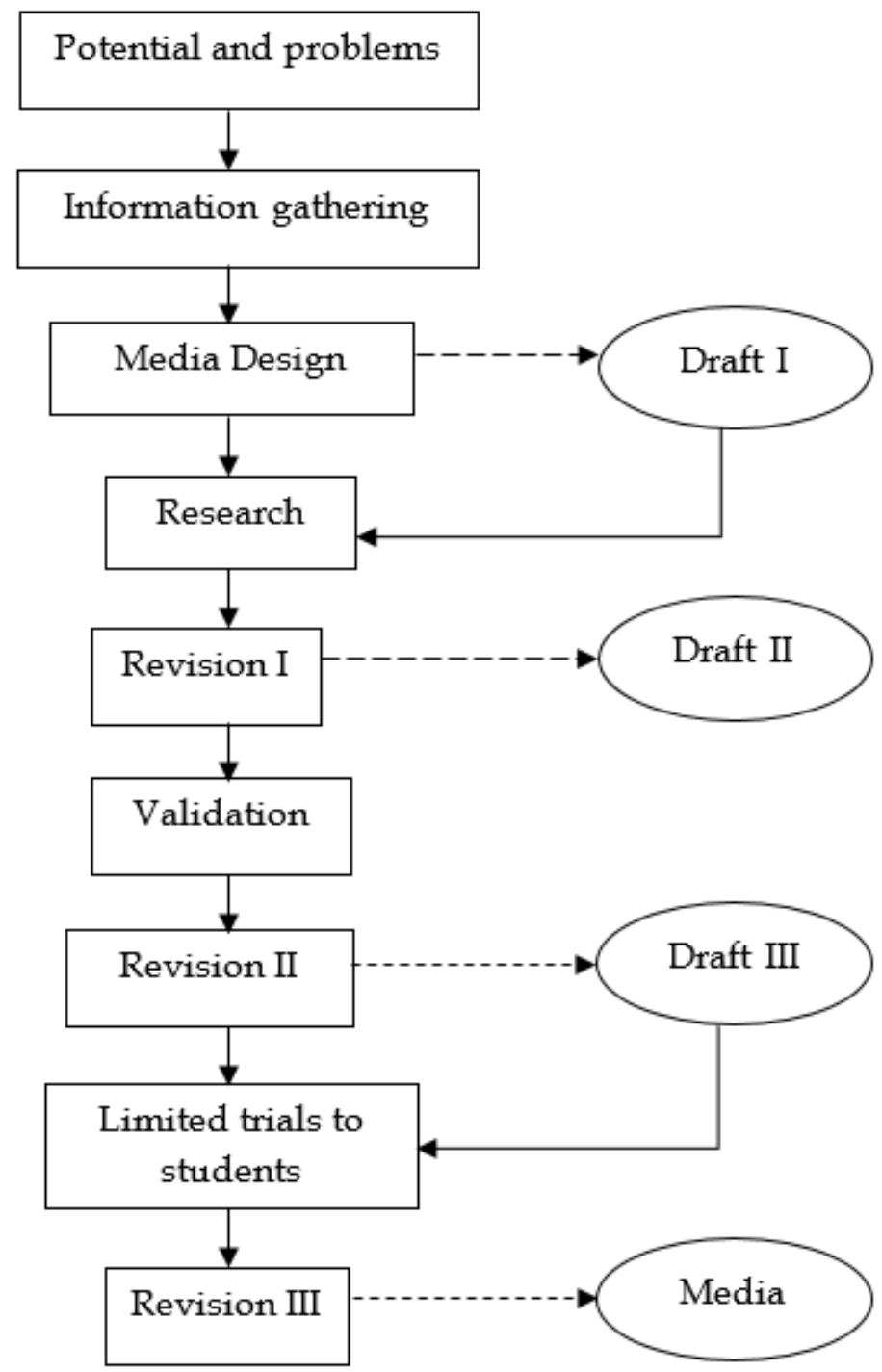

Figure 1. Research design.

The results of the analysis from the validator that has been obtained will be used to determine the feasibility of the flipbook-type e-book being developed. The value obtained is then interpreted for its feasibility as in Table 2.

Table 2. Validator review score interpretation.

\begin{tabular}{cc}
\hline Criteria & Validator review score \\
\hline Completely valid & $86-100$ \\
Valid & $71-85$ \\
Quite valid & $56-70$ \\
Less valid & $41-55$ \\
Not valid & $\leq 40$ \\
\hline
\end{tabular}

The validation criteria also calculated the correlation coefficient (r) using SPSS version 25. The results were then compared with the $r$ table. $R$ count is greater than $r$ table then it is declared valid. The implementation observation sheet is used as a reference to determine the practicality of the flipbook-type e-book when used during the learning process. The observation sheet contains statements that will be filled out by 
Feasibility and Practically of Learning Resources Flipbook Identification of Basidiomycota Mushrooms for Senior High School Students

four observers. Observation of the implementation of the e-book is done by giving a checklist $(\sqrt{ })$ on the activities that are carried out and putting a mark $(x)$ on the activities that are not carried out in the column containing the activities of students when learning using flipbooks. Observation activities were carried out by four observers, where each observer observed a group of five students. The analysis of the implementation of the e-book was carried out using the Guttman Scale as shown in Table 3.

Table 3. Guttman scale.

\begin{tabular}{cc}
\hline Answer & Score \\
\hline Yes & 1 \\
No & 0 \\
\hline
\end{tabular}

The score obtained from the observations is calculated on average using the following formula:

$$
\% \text { Ebook Feasibility }=\frac{\sum \text { score answer }{ }^{~} Y e s^{\prime \prime}}{\text { score } \text { maximum }} \times 100 \%
$$

The results of the analysis of the implementation of the e-book are used to determine the implementation of the flipbook type e-book which was developed using the practical interpretation as shown in Table 4.

Table 4. Criteria for interpretation of practicality of e-books.

\begin{tabular}{cc}
\hline Average score (\%) & Category \\
\hline $1-48$ & Not practical \\
$49-61$ & Less practical \\
$62-74$ & Quite practical \\
$75-87$ & Practical \\
$88-100$ & Very practical \\
\hline
\end{tabular}

\section{RESULTS AND DISCUSSION}

This study resulted in a flipbook-type e-book learning media on material for identification of Basidiomycota fungi that was valid and practical. The initial stage in research on the development of an e-book type flipbook identification of Basidiomycota fungi is the stage of compiling the initial design of the e-book. Furthermore, the initial design will be reviewed by the supervisor as an initial draft of the e-book. Then, a review and validation were carried out by the three validators in order to obtain suggestions for improvement. The revision of the e-book is carried out in accordance with the advice of the validator so as to produce an e-book that is ready to be tested on students. The results of the review and revision of the developed e-book can be seen in Table 5 .

Table 5. Results of suggestions and revisions of flipbook-type e-books.

\begin{tabular}{lll}
\hline No. & \multicolumn{1}{c}{ Suggestion } & \multicolumn{1}{c}{ Revision results } \\
\hline 1. & The role of fungi in life is added as an & Adding a role in life as an explicit part of \\
explicit part of Basic Competencies. & Basic Competencies. \\
The role of mushrooms in the edible & The role of mushrooms in the edible \\
category before revision: & category after revision:
\end{tabular}


Feasibility and Practically of Learning Resources Flipbook Identification of Basidiomycota Mushrooms for Senior High School Students

\begin{tabular}{|c|c|c|}
\hline No. & Suggestion & Revision results \\
\hline \multirow{3}{*}{2.} & Jamur yang dapat dimakan (edible). & $\begin{array}{l}\text { Jamur yang dapat dimakan (edible). Selain kaya gizi untuk } \\
\text { dikonsumsiekstrak jamur shitiake sebagaiaisumber pengobatan } \\
\text { sehingga menanmbah sistem kekebalan tubuh. }\end{array}$ \\
\hline & There is no bibliography in the e-book. & $\begin{array}{l}\text { Add and complete the bibliography. } \\
\text { E-book after revision: }\end{array}$ \\
\hline & & 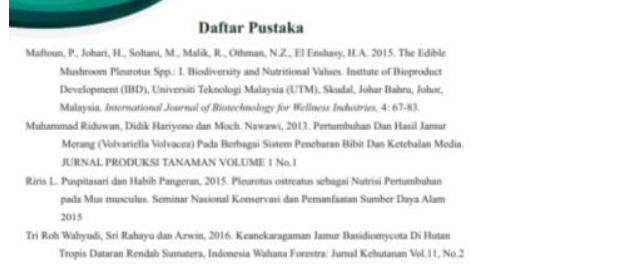 \\
\hline 3. & $\begin{array}{l}\text { The library sources in each description are } \\
\text { added. } \\
\text { E-book before revision: } \\
\text { ditemukan di hutan tropis di bawah } \\
\text { d dibawah tanaman berkayu. }\end{array}$ & $\begin{array}{l}\text { Add library sources in each description. } \\
\text { E-book after revision: } \\
\text { ditemukan di hutan tropis di bawah } \\
\text { u dibawah tanaman berkayu. }\end{array}$ \\
\hline & an (edible). & Sumber : (Riris dan Habib, 2015) \\
\hline
\end{tabular}

The flipbook type e-book that has been developed will then be assessed for validity by three validators, namely two biology lecturers and one high school biology teacher. The results of the validation assessment by the three validators can be seen in Table 6 .

Table 6. Validation results for flipbook type e-books

\begin{tabular}{|c|c|c|c|c|c|c|}
\hline \multirow{2}{*}{ No. } & \multirow{2}{*}{ Statement } & \multicolumn{3}{|c|}{ Score } & \multirow{2}{*}{ Average } & \multirow{2}{*}{ Category } \\
\hline & & V1 & V2 & V3 & & \\
\hline \multicolumn{7}{|c|}{ A. CONTENT ELIGIBILITY } \\
\hline 1. & Compatibility with Basic Competencies & 4 & 3 & 4 & 3,67 & \\
\hline 2. & Concept accuracy & 4 & 3 & 3 & 3,33 & \\
\hline 3. & Concept easy to understand & 3 & 4 & 4 & 3,67 & \\
\hline 4. & Conformity with the development of science & 4 & 4 & 4 & 4 & \\
\hline 5. & $\begin{array}{l}\text { The inclusion of the image corresponds to the } \\
\text { mushrooms in the environment }\end{array}$ & 4 & 4 & 4 & 4 & \\
\hline 6. & $\begin{array}{l}\text { The inclusion of Edible Mushroom (can be } \\
\text { consumed) and Poisonous Mushroom is } \\
\text { distinguished (cannot be consumed) }\end{array}$ & 4 & 3 & 4 & 3,66 & \\
\hline 7. & Inclusion of description & 3 & 3 & 3 & 3 & \\
\hline 8. & Classification inclusion & 4 & 4 & 3 & 3,66 & \\
\hline 9. & Inclusion of identification features & 4 & 3 & 3 & 3,33 & \\
\hline 10. & Inclusion of Basidiomycota mushroom material & 3 & 3 & 3 & 3 & \\
\hline \multicolumn{2}{|r|}{ Validation Average Score } & & & & 3,53 & $\begin{array}{l}\text { Very } \\
\text { Valid }\end{array}$ \\
\hline \multicolumn{7}{|c|}{ B. LANGUAGE ELIGIBILITY } \\
\hline & $\begin{array}{l}\text { Language-communication aspects that must be } \\
\text { met } \\
\text { a. Simple }\end{array}$ & 4 & 4 & 3 & 3,67 & \\
\hline & b. Interesting & 4 & 3 & 4 & 3,67 & \\
\hline & $\begin{array}{l}\text { c. Easy to understand } \\
\text { The accuracy of the language aspects that must }\end{array}$ & 4 & 3 & 4 & 3,67 & \\
\hline 2. & $\begin{array}{l}\text { be met } \\
\text { a. According to big sentence }\end{array}$ & 4 & 3 & 3 & 3,33 & \\
\hline
\end{tabular}


Feasibility and Practically of Learning Resources Flipbook Identification of Basidiomycota Mushrooms for Senior High School Students

\begin{tabular}{|c|c|c|c|c|c|c|}
\hline \multirow{4}{*}{ No. } & \multirow{2}{*}{ Statement } & \multicolumn{3}{|c|}{ Score } & \multirow{2}{*}{ Average } & \multirow{2}{*}{ Category } \\
\hline & & V1 & V2 & V3 & & \\
\hline & b. Terms according to scientific agreement & 4 & 4 & 3 & 3,67 & \\
\hline & Validation Average Score & & & & 3,60 & $\begin{array}{l}\text { Very } \\
\text { Valid }\end{array}$ \\
\hline \multicolumn{7}{|c|}{ C. DISPLAY ELIGIBILITY } \\
\hline 1. & $\begin{array}{l}\text { Ease of use of flipbook e-book as identification } \\
\text { e-book }\end{array}$ & 4 & 3 & 4 & 3,67 & \\
\hline 2. & Easy to carry & 4 & 4 & 4 & 4 & \\
\hline 3. & $\begin{array}{l}\text { Mushroom Identification flipbook cover design } \\
\text { is attractive }\end{array}$ & 4 & 4 & 4 & 4 & \\
\hline 4. & Font type size & 4 & 4 & 4 & 4 & \\
\hline & $\begin{array}{l}\text { Mushroom Identification flipbook layout } \\
\text { aspects that must be filled: }\end{array}$ & & & & & \\
\hline \multirow[t]{4}{*}{5.} & $\begin{array}{l}\text { a. Consistent : (cover mushroom species, } \\
\text { fungal parts, fungal classification, mushroom } \\
\text { description) }\end{array}$ & 4 & 3 & 4 & 3,67 & \\
\hline & $\begin{array}{l}\text { b. Harmonious: placement of layout elements } \\
\text { (text and illustrations) proportionally on the } \\
\text { print plane }\end{array}$ & 4 & 3 & 4 & 3,67 & \\
\hline & $\begin{array}{l}\text { c. Completed : The title of each discussion is } \\
\text { written }\end{array}$ & 4 & 3 & 4 & 3,67 & \\
\hline & $\begin{array}{l}\text { The attractiveness of color and illustration } \\
\text { aspects that must be filled: } \\
\text { a. Harmonious color }\end{array}$ & 4 & 3 & 4 & 3,67 & \\
\hline \multirow{4}{*}{6.} & b. Proportional illustration on the print plane & 4 & 4 & 4 & 4 & \\
\hline & c. Illustration looks clear & 4 & 4 & 4 & 4 & \\
\hline & d. Interesting illustration & 4 & 4 & 4 & 4 & \\
\hline & Validation Average Score & & & & 3,84 & $\begin{array}{l}\text { Very } \\
\text { Valid }\end{array}$ \\
\hline
\end{tabular}

The results of the correlation coefficient (r) to determine the validity of the flipbook that has been developed are as follows in Table 7.

Table 7. R calculate the validation of the Flipbook type E-Book.

\begin{tabular}{|c|c|c|c|}
\hline Aspect & $\mathbf{R}_{\text {count }}$ & $\mathbf{r}_{\text {table }(0,05)}$ & Category \\
\hline Content & 0,999 & 0,997 & Valid \\
\hline Language & 0,998 & 0,997 & Valid \\
\hline Display & 0,999 & 0,997 & Valid \\
\hline Average & & & Valid \\
\hline
\end{tabular}

Table 8. Reliability Statistics.

\begin{tabular}{cc}
\hline Cronbach's Alpha & N of items \\
\hline .857 & 26 \\
\hline
\end{tabular}

Based on the analysis results using the correlation coefficient (r), it resulted that the average result of Rcount obtained a score of 0.999 . Based on Table 8., it is found that the value of Cronbach's Alpha on reliable statistics gets a score of 0.857 . The validity of content, language, and appearance is reliable if Cronbach's Alpha value is $>0.6$. In the calculation above, it is known that the value of Cronbach's Alpha is $0.857>0.6$, so it is said to be reliable.

Based on the validation results from the three validators, the feasibility of the contents of the e-book developed is following the Basic Competencies. In the component of conformity with the development of science and the inclusion of images 
following the fungi in the environment, it obtained a perfect validation score of 4 with a very feasible category. In the components of conformity with Basic Competencies, easyto-understand concepts, the inclusion of edible mushrooms, and the inclusion of classifications, the validation score is 3.66 , with a very decent category. In the component of concept accuracy and the inclusion of identification features, a validation score of 3.33 was obtained, with a decent category. The overall content feasibility aspect obtained a validity result of $88.2 \%$ so that it can be declared very feasibly. It is in accordance with Widiasmoro (2017) opinion, which states that the provision of material must be adjusted to the needs and level of understanding and make it easier for students to receive the lessons.

In the components of inclusion of descriptions and inclusion of Basidiomycota mushroom material, a validation score of 3 was obtained in the proper category. The low score obtained for these components is because each description does not include library sources, and the role of mushrooms listed is still lacking. Regarding this, the researcher has made improvements, and revisions following the input and suggestions given by the validator by adding library sources to each description in the e-book developed and adding the role of mushrooms in everyday life. Jeng et al. (2010) state that mobile technology provides convenience in contextual learning and is in accordance with students' daily lives. The role of mushrooms in everyday life is added to the e-book, as additional information that can be useful in everyday life. This is supported by a similar statement from Sardiman (2014), where to make visual media such as e-books must be authentic or natural and can grow student activities and achieve learning goals.

The feasibility of the language in the developed e-book is assessed based on the components of language communication, including simple, engaging, and easy to understand; as well as language accuracy, which includes conformity with extensive sentences, and terms that are following the scientific agreement. The validation results on the feasibility of the language obtained a validation score of 3.60 with a very feasible category.

The language used in the developed e-book has been adapted to Enhanced Spelling (EYD) so that the sentences contained in the e-book are appropriate and well-organized. The terms used have also been adapted to a scientific agreement. Teaching materials are said to be good, namely when (1) the scope of the material or content is in accordance with the curriculum, (2) the presentation of the material meets the learning principles, (3) the language and readability are good, and (4) the format of the book or graphics is interesting (Puskurbuk, 2012). In terms of language, the sentences used in the e-book use sentences that are easy to understand, use appropriate punctuation marks, and do not cause double interpretation.

The feasibility of the appearance of the developed e-book is assessed based on the ease of use of the e-book as a means of identification, portability, attractive design, font size, the layout of the e-book, and attractiveness of colors and illustrations in the e-book. In the ease of portability sub-component, the e-book cover design, font size, and attractiveness of colors and graphics used obtained a perfect validation score of 4 with a very decent category. This component gets the maximum score because the pictures and illustrations used in the e-book are clear and have the appropriate size, making it easier for students to understand. The writing format used in the e-book has the appropriate size so that it can be read correctly. The colors used in writing are also contrasting so they are easy to read. A similar study resulted in developing an e-book 
Feasibility and Practically of Learning Resources Flipbook Identification of Basidiomycota Mushrooms for Senior High School Students

with media validation obtaining a percentage of $80 \%$ and suitable for use. This is in accordance with the statement from Arsyad (2015) which states that words in visual media must use simple letters with a font style that is easy to read and not too diverse in one display or a series of visual displays.

In the sub-component of the ease of use of the e-book and the layout of the e-book, it obtained a validation score of 3.67 with a very decent category. Colorful pictures accompany the developed e-book, and the e-book layout (layout) is arranged so that it is easy to read. Colored images and illustrations can help readers visualize the material contained in the e-book more quickly. The mushroom photo on the flipbook is adjusted to the original shape so that it can facilitate and increase students' learning motivation. It is supported by the opinion of Ami (2012), which states that the brain will respond faster in receiving meaning from writing if colorful pictures or illustrations accompany it.

The practicality of the e-book is seen from the implementation of the activities listed in the e-book that was developed in the learning process. Observation of the performance of the e-book is not only done with the instrument of observation of the implementation but also on the e-book used by students. The results of observations on the implementation of flipbook e-books in learning can be seen in Table 7.

Table 7. E-book implementation observation results.

\begin{tabular}{|c|c|c|}
\hline No. & Activities in e-book & Implementation \\
\hline 1. & Students start learning by praying & 100 \\
\hline 2. & Students focus on listening to the teacher's explanation & 90 \\
\hline 3. & $\begin{array}{l}\text { Students are interested in the teacher's explanation regarding } \\
\text { Flipbook }\end{array}$ & 75 \\
\hline 4. & Students read the diversity of Basidiomycota listed on the Flipbook & 70 \\
\hline 5. & Students read the instructions for use listed on the Flipbook & 75 \\
\hline 6. & Students have an interest in analyzing mushrooms using Flipbook & 90 \\
\hline 7. & Students observe the mushroom specimens provided & 85 \\
\hline 8. & $\begin{array}{l}\text { Students hold and check the completeness of the morphology of } \\
\text { existing specimens }\end{array}$ & 90 \\
\hline 9. & $\begin{array}{l}\text { Students read the division identification feature sheet to find out the } \\
\text { parts of the Basidiomycota mushroom specimens that were identified }\end{array}$ & 100 \\
\hline 10. & $\begin{array}{l}\text { Students match the characteristics of Basidiomycota mushrooms with } \\
\text { photos in the Flipbook Identification of Basidiomycota mushrooms }\end{array}$ & 75 \\
\hline 11. & $\begin{array}{l}\text { Students match the characteristics of Basidiomycota mushrooms with } \\
\text { photos in the Flipbook Identification of Basidiomycota fungi }\end{array}$ & 80 \\
\hline 12. & $\begin{array}{l}\text { Students match the description of Basidiomycota mushrooms with } \\
\text { photos in the Flipbook. Identification of Basidiomycota mushrooms }\end{array}$ & 95 \\
\hline 13. & $\begin{array}{l}\text { Students write down the classification of Basidiomycota fungal } \\
\text { specimens listed on the Fungal Identification Flipbook }\end{array}$ & 85 \\
\hline 14. & $\begin{array}{l}\text { Students write down the family name of the Basidiomycota } \\
\text { mushroom specimen listed on the Mushroom Identification Flipbook }\end{array}$ & 85 \\
\hline 15. & $\begin{array}{l}\text { Students write descriptions of Basidiomycota mushroom specimens } \\
\text { listed on the Fungal Identification Flipbook }\end{array}$ & 100 \\
\hline 16. & Students draw conclusions from the identification results & 100 \\
\hline \multicolumn{2}{|r|}{ Average Total } & 87.2 \\
\hline \multicolumn{2}{|r|}{ Category } & Practical \\
\hline
\end{tabular}

Based on the data from the observations in Table 7, the data from the implementation observations will be interpreted practically using the interpretation criteria from Ratumanan (2011). The results of the implementation observations in Table 7 show that 
the implementation of the flipbook type e-book is practical to use because students are actively involved in every activity listed in the e-book. The average practicality of the ebook got a score of $87.2 \%$ in the practical category. It shows that learning using flipbook-type e-books can make students more active and attentive to ongoing learning activities so that all stages of activities are carried out. The implementation of all phases of activities makes the learning process fun. Flipbook-type e-book media can attract students' interest in learning in the learning process. This is in accordance with Amin and Mayasari (2015) statement that the weblog-based digital learning media that was created helps lecturers and students in learning as a tool in completing assignments, and students are interested in the products developed.

A similar statement to research from Chuang \& Chen in Lubis (2015) states that digital learning media (such as e-books) can facilitate students to learn anytime and anywhere and increase students' motivation and memory. Similar research has been conducted by Sakat et al (2012), where learning using technology-based media can increase motivation because learning becomes more interactive and fun.

The practicality of learning media can be seen from the ease of teachers and students in utilizing learning media that are in accordance with the situation and conditions of students, teachers, and schools, as well as the allocated time so that students and teachers give positive responses to the learning that has been done. This is supported by a statement from Nurrita (2018), which states that learning media are tools that can assist the teaching and learning process so that the messages and meanings conveyed become clearer and learning objectives can be achieved effectively and efficiently.

According to Lubis and Ikhksan (2015) the use of android applications has resulted in a significant increase between learning motivation and student cognitive achievement. Students are also able to complete tasks with the help of the android application. Based on research conducted by Fredyana \& Dewanto (2016), androidbased learning media is very feasible and receives positive responses from students and improves learning outcomes so that the android application is feasible to use as a learning medium (Yuntoto, 2015).

Some aspects get a low score on implementation observations: Students read the Basidiomycota diversity listed on the Flipbook, which receives an implementation score of $70 \%$. The low implementation score obtained in this aspect is due to the limited time allocation at the implementation or trial phase. The flipbook-type e-book developed is an application that needs to be installed first, so it takes longer. Students do not have enough time to read the diversity of Basidiomycota listed in the flipbook with this limited time. So to overcome this, the researcher gave a direct explanation orally about the variety of Basidiomycota fungi to students.

\section{CONCLUSIONS}

Based on the research results on the development of the flipbook type e-book on the identification of Basidiomycota mushrooms to train students' learning motivation, it can be concluded that the flipbook type e-book developed is valid practical. Based on practicality in terms of implementation, flipbook-type e-books get an average percentage of $87.2 \%$. Based on the validity of content feasibility, language feasibility, and display feasibility, the average percentage value of eligibility is 3.84 . This study was only tested on a limited basis to 20 students, so it is necessary to do follow-up research to apply e-books on a broader scale and add time allocation to students when reading 
Feasibility and Practically of Learning Resources Flipbook Identification of Basidiomycota Mushrooms for Senior High School Students

the diversity of mushrooms in e-books so that students can read the entire material in ebooks.

\section{REFERENCES}

Ami, M. S., Susantini, E., \& Raharjo. (2012). Pengembangan buku saku materi sistem ekskresi manusia di SMA/MA kelas XI. BioEdu, 1(2), 10-13.

Amin, A. K., \& Mayasari, N. (2015). Pengembangan media pembelajaran berbentuk aplikasi android berbasis weblog untuk meningkatkan hasil belajar mahasiswa pendidikan matematika IKIP PGRI Bojonegoro. Magistra, 94(1), 12-23.

Arsyad, A. (2015). Media pembelajaran. Jakarta: Rajawali Pers.

Awaludin. (2017). Pengembangan buku teks sintaksis bahasa indonesia. Yogyakarta: Deepublish.

Daniel, M., Sulviana, \& Yusminah H. (2018). Penerapan media buku elektronik biologi untuk meningkatkan motivasi aktivitas dan hasil belajar peserta didik pada peserta didik XI IPA 1 SMAN 5 Sidrap. Makassar: Universitas Negeri Makassar.

Fredyana, C. A., \& Dewanto. (2016). Pengembangan media pembelajaran berbasis android pada mata pelajaran teknologi dasar otomotif untuk kelas x SMK negeri 3 Buduran Sidoarjo. JPTM, 5(3), 40-46.

Fithriyah, I., \& As'ari, A. R. (2013). Pengembangan media pembelajaran buku saku materi luas permukaan bangun ruang untuk jenjang SMP. Malang: Universitas Negeri Malang.

Handika, J. (2012). Efektivitas media pembelajaran IM3 ditinjau dari motivasi belajar. Jurnal Pendidikan IPA Indonesia, 2(1), 109-114.

Hess, S. (2014). Digital media and student learning: impact of electronic books on motivation and achievement. New England Reading Associatiion Journal, 49(2), 35-39.

Lubis, I. R., \& Ikhsan J. (2015). Pengembangan media pembelajaran kimia berbasis android untuk meningkatkan motivasi belajar dan prestasi kognitif peserta didik SMA. Jurnal Pendidikan Inovasi IPA, 1(2), 191-201. https://doi.org/10.21831/jipi.v1i2.7504.

Muhlas, \& Kuntjoro, S. (2019). Pengembangan e-book tipe flipbook berbasis literasi sains pada materi ekologi kelas X SMA. Jurnal Berkala Ilmiah Pendidikan Biologi (BioEdu), 8(1), $58-62$.

Nurrita, T. (2018). Pengembangan media pembelajaran untuk meningkatkan hasil belajar siswa. Misykat, 3(1), 171-187. http:// doi.org/10.33511/misykat.v3n1.171

Prasetyo, Y. D., Yektyastuti, R., Solihah, M., Ikhsan, J., \& Sugiyarto, K. H. (2015). Pengaruh penggunaan media pembelajaran kimia berbasis android terhadap peningkatan motivasi belajar siswa SMA. Seminar Nasional Pendidikan Sains, 1(1), 252-258.

Sakat, A. A., Zin, M. Z. M., Muhamad, R., Ahmad, A., Ahmad, N. A., \& Kasmo, M. A. (2012). Educational technology media method in teaching and learning progress. American Journal of Applied Sciences, 9(6), 874-878. https://doi.org/10.3844/ajassp.2012.874.878

Sardiman, A. M. (2014). Interaksi dan motivasi belajar dan mengajar. Jakarta: Raja Grafindo Persada.

Uno, H. B. (2015). Teori motivasi \& pengukurannya. Jakarta: Badan Penerbit

Widiasmoro, E. (2017). Strategi dan metode mengajar siswa di luar kelas (outdoor learning) secara aktif, kreatif, inspiratif, dan komunikatif. Yogyakarta: Ar-ruzz Media

Yuntoto, S. (2015). Pengembangan aplikasi android sebagai media pembelajaran kompetensi pengoperasian sistem pengendali elektronik pada siswa kelas xi smkn Pengasih. Skripsi: Universitas Negeri Yogyakarta 
Feasibility and Practically of Learning Resources Flipbook Identification of Basidiomycota Mushrooms for Senior High School Students

*Fajrul Falah, S.Pd. (Corresponding Author)
Postgraduate Programme, Science Education Study Program
Universitas Negeri Surabaya,
Continuing Program Development, Jl. Unesa Lidah Wetan, Surabaya, East Java, Indonesia.
Email: fajrul.19023@mhs.unesa.ac.id

Dr. Sifak Indana, M.Pd.

Postgraduate Programme, Science Education Study Program

Universitas Negeri Surabaya,

Continuing Program Development, Jl. Unesa Lidah Wetan, Surabaya, East Java, Indonesia.

Email: $\underline{\text { sifakindana@unesa.ac.id }}$

\section{Prof. Dr. Tukiran, M.Si.}

Postgraduate Programme, Science Education Study Program

Universitas Negeri Surabaya,

Continuing Program Development, Jl. Unesa Lidah Wetan, Surabaya, East Java, Indonesia.

Email: tukiran@unesa.ac.id 